\title{
THE SPLENDID DURABILITY OF THE PROVISIONAL: A TRIBUTE TO EURATOM
}

\author{
Jakub Handrlica *
}

Summary: Sixty years ago, on 1 January 1958, the Treaty establishing the European Atomic Energy Community of 1957 entered into force. In contrast to the Treaty establishing the European Coal and Steel Community of 1951, the Treaty establishing the European Atomic Energy Community of 1957 did not provide for any explicit limitation of the Community's existence in its provisions. As a consequence, the key provisions of the Treaty, establishing the Community's powers and competences, have remained virtually untouched until today. This article analyses this Community from three different perspectives. Firstly, attention is paid to the clauses enabling prospective amendments, adjustments, and further specification of the scope of application. Consequently, it is argued that to some extent the Community was originally designed as a 'provisional' one. Secondly, the article deals with those provisions of the Euratom Treaty which originally provided for certain competences of the Community in nuclear research, the supply of ores, source materials and special fissile materials and the insurance of nuclear liability. Due to the fact that these competences have never been used, it is argued that from this perspective the Euratom Community can be viewed as a 'static' Community. Thirdly, the extensive interpretation of the Euratom competences in the area of health and safety by the Court of Justice will be addressed. Based on this extensive interpretation, the Euratom Community launched its legislative activity in the area of nuclear safety in order to address this key issue of peaceful use of nuclear energy. From this perspective, the Community is to be regarded a 'flexible' one. The $60^{\text {th }}$ anniversary of the Euratom Treaty represents a good opportunity to revisit in detail the characteristic features of the Euratom Community from these different perspectives.

\section{Introduction}

The Treaty establishing the European Atomic Energy Community (hereinafter: the Treaty) was signed by the representatives of the six

\footnotetext{
Associate Professor, Faculty of Law, Charles University in Prague, Czech Republic; https://orcid.org/0000-0003-2274-0221. Contact: jakub.handrlica@email.cz. DOI: 10.3935/cyelp.14.2018.301.
} 
States ${ }^{1}$ in Rome on 25 March $1957 .{ }^{2}$ Pursuant to its Article 224, the Treaty entered into force on the first day of the month following the deposit of the instrument of ratification by the last signatory State to take this step, ie on 1 January 1958. The intentions of the six States were laid down in the Preamble to the Treaty: the Euratom Community was established as a reflection of the belief that "nuclear energy represents an essential resource for the development and invigoration of industry and will permit the advancement of the cause of peace'. Consequently, the six States intended on one hand to 'create the conditions necessary for the development of a powerful nuclear industry which will provide extensive energy resources, lead to the modernisation of technical processes and contribute, through its many other applications, to the prosperity of their peoples', and on the other hand to 'create the conditions of safety necessary to eliminate hazards to the life and health of the public'. Facing contemporary developments, ${ }^{3}$ the Preamble of the Treaty highlighted that the joint effort of the six States must be "undertaken without delay'.

Taking the intentions of the six governments into regard, one can easily understand that the provisions of the Treaty directly aim at supporting the development of the nuclear industry through the newly established Community. The Contracting Parties established the competences of the Community in ten areas, ${ }^{4}$ seven of which explicitly address the further development of the nuclear industry. The three remaining areas cover issues of the protection of health against the dangers arising from ionising radiation, safeguards, and international relations. All these areas are the subject of regulation by Title II of the Euratom Treaty.

\footnotetext{
${ }^{1}$ Belgium, Federal Republic of Germany, France, Italy, Luxembourg and the Netherlands.

${ }^{2}$ See E Conze, 'La coopération franco-germano-italienne dans le domaine nucléaire dans les années 1957-1958' (1990) 104(1) Revue d'historié diplomatique 115; M Dumoulin, P Guillen and M Vaïsse, L'énergie nucléaire en Europe: Des origines à Euratom (Peter Lang 1994) 11; P Guillen, 'La France et la négociation des traités de Rome: l'Euratom' in E Serra (ed), Relance Européenne et les traités de Rome (Bruylant 1989); H Nieburg, 'European Atomic Energy Community: A Study in Coalition Politics' (1963) 15(3) World Politics 597; P Weilemann, 'Die deutsche Haltung während der Euratom-Verhaltungen' in E Serra (ed), Relance Européenne et les traités de Rome (Bruylant 1989).

${ }^{3}$ It was the publication of the 'Armand Report' in 1955 which urged the governments of the six States to commence the construction of their own nuclear industry immediately to address the risk of a prospective shortage of energy resources.

${ }^{4}$ Promotion of research (Chapter 1, Articles 4-11), dissemination of information (Chapter 2, Articles 12-29), health and safety (Chapter 3, Articles 30-39), investments (Chapter 4, Articles 40-44), joint undertakings (Chapter 5, Articles 45-51), supplies (Chapter 6, Articles 52-76), safeguards (Chapter 7, Articles 77-85), property ownership (Chapter 8, Articles 86-91), the common nuclear market (Chapter 9, Articles 92-99), international relations (Chapter 10, Articles 101-106).
} 
During the 1950s and 1960s, the establishment of Euratom triggered relatively wide interest from legal academia. ${ }^{5}$ Euratom became the subject of several dissertations ${ }^{6}$ and the Brussels-based 'Librairie encyclopédique' published the first commentary on the provisions of the Treaty. ${ }^{7}$ However, further developments caused a waning of academic interest in the Euratom Community. During the 1970s, it became clear that Euratom's competences would not be executed in the way the Treaty had foreseen, a fact described by some authors as the 'final crisis of Euratom'. ${ }^{8}$ In the following decades, Euratom triggered academic attention only occasionally, in particular with regard to its immunity to any amendments or changes. ${ }^{9}$ Subsequently, the Euratom Community was referred to as being 'like a Chinese girl-child, exposed after birth

\footnotetext{
${ }^{5}$ See K Cohen, 'European Atomic Energy Community' (1959) 7(1) Journal of Industrial Economics 79; R Efron and A Nanes, 'The Common Market and Euratom Treaties: Supranationality and the Integration of Europe' (1957) 6(4) ICLQ 670; M Gaudet, 'Euratom' in JL Weinstein (ed), Progress in Nuclear Energy. Law and Administration (Pergamon Press 1959); S Gorove, 'Lessons from the Control of the Peaceful Uses of Atomic Energy in Euratom' (1964) 58 American Society of International Law Proceedings 136; H Hahn, 'Control under Euratom Compact' (1958) 7(1) AJCL 39; H Hahn, 'Euratom: Conception of an International Personality' (1958) 71(6) Harvard Law Review 1001; P Hay, 'Patent Aspects of Domestic Law, Euratom and the International Atomic Energy Agency' (1958) 56(4) MLR 770; J Hébert, 'Communauté européenne de l'énergie atomique' (1965) 2(1) RTDEur 41; J Johnson, 'An Introduction to Euratom' (1957/1958) 13 Business Lawyer 801; P Mathijsen, 'Problems Connected with the Creation of Euratom' (1961) 26(4) Law and Contemporary Problems 438; U Meyer-Cording, 'Europa und der Euratomvertrag' in Europa Union Deutschland (ed), Euratom: Wirtschaftliche und politische Probleme der Atomenergie (Europa-Union 1957); N Pelzer, 'Die rechtliche Problematik der Beschränkung der deutschen Atomwirtschaft durch den Euratomvertrag' (1962) Der Betrieb; L Scheinman, 'Euratom: Nuclear Integration in Europe' (1966/1967) 36(1) International Conciliation 1; G Vedel, 'Euratom' (1958) 9(2) Revue économique 225; D Vigner and G Fischer, 'Euratom' (1956) 2(5) AFDI 695, etc.

${ }^{6}$ Eg K Ballerstedt, Das Eigentum an Kernbrennstoffen (Veröffentlichungen des Instituts für Energierecht an der Universität Bonn 1962); TW Vogelaar, Het eigendomsrecht van Euratom over bijzondere splijstoffen (Gorcum \& Comp NV 1961), etc.

7 J Errera, E Symon, J Meulen and L Vernaeve, Euratom: Analyse et Commentaires du Traité (Librairie Encyclopédique 1958).

${ }^{8}$ C Deubner, 'The Final Crisis of Euratom' (1979) 2(1) Current Research on Peace and Violence 53.

${ }^{9}$ PM Barnes, 'The Resurrection of the Euratom Treaty: Contributing to the Legal and Constitutional Framework for Secure, Competitive and Sustainable Energy in European Union' in T Etty and H Somsen (eds), Yearbook of European Environmental Law (OUP 2008); PM Barnes, The Politics of Nuclear Energy in the European Union. Framing the Discourse: Actors, Positions and Dynamics (Barbara Budrich Publishers 2018); I Cenevska, 'The European Parliament and the European Atomic Energy Community: A Legitimacy Crisis?' (2010) 35(3) ELR 415; C True, 'EU-Kompetenzen für Energierecht, Gesundheitsschutz und Umweltschutz und die Position der Euratom nach dem Verfassungsentwurf des Konvents' (2004) Juristenzeitung 779; S Wolf, 'Zur Zukunft des Euratom-Vertrags' (2006) 29(4) Integration 297; S Wolf, 'Intergration durch Kernfusion? Zur Wiederbelebung der Euratom - Gründungsmythen' (2007) 25(1) Forum Recht 26, etc.
} 
because the parents did not want it to live', ${ }^{10}$ 'a dormant serpent,, "an outsider', ${ }^{12}$ 'an invisible creature, ${ }^{13}$ etc.

The Euratom Community was referred to as having already been forgotten a decade after its establishment by some authors. ${ }^{14}$ Other authors have recently pointed out that the Euratom Community still represents a kind of terra incognita for scholars of EU law. ${ }^{15}$ In this respect, this article aims to analyse the Euratom Community from three different points of view.

Firstly, the provisions providing for the further amendments, adjustments, and additional specification of the scope of application of the Treaty will be analysed. Taking the early stage of the nuclear industry into regard, these provisions were designed to reflect the further developments of this new industrial branch and allow for necessary changes in the Treaty. Having said this, the concept of the Euratom Community can be described a 'provisional' one.

Secondly, the article will point out the existence of several provisions which were originally drafted to give the Euratom Community certain competences, but which have never actually been used by the Community. Consequently, from this point of view, the Community can be regarded as a 'static' one.

Thirdly, the Euratom Community will be analysed from the point of view of its recent norm-making activity. While originally intended mainly for the purposes of the further development of the nuclear industry, the Euratom Community has been gradually transformed into a Community establishing binding standards of nuclear safety in order to protect citizens and the environment. Consequently, from this point of view, it can be regarded as a 'flexible' Community.

The current $60^{\text {th }}$ anniversary of the Treaty represents a good opportunity to deal in detail with the Euratom Community from these three different perspectives and, consequently, to revisit the characteristic features of this Community.

${ }^{10}$ D Allen, 'The Euratom Treaty, Chapter VI: New Hope or False Dawn?' (1983) 20(3) CMLR 473.

${ }^{11}$ N Prieto Serrano, 'Wakening the Serpent: Reflections on the Possible Modification of the Euratom Treaty' (2006) 1(1) IJNucL 14.

12 I Cenevska, The European Atomic Energy Community in the European Union Context: The 'Outsider' Within (Brill Nijhoff 2016).

${ }^{13}$ J Sellarés Sella, 'El Euratom subsiste, invisible e incompatible con el tinglado comunitario' in JM Pérez de Nanclares (ed), El Tratado de Lisboa: la salida de la crisis constitucional (Iustel 2007).

${ }_{14}$ TW Vogelaar, 'Euratom: de vergeten gemeenschap' (1967) 8(1) Nieuw Europa: maandblat van de Europese Beweging in Nederland 14.

${ }^{15}$ A Södersten, Euratom at the Crossroads (Edward Elgar Publishing 2018) 1. 


\section{A 'provisional' community}

When signing the text of the Treaty, the governments of the six States were aware that the newly born nuclear industry was in the stage of infancy and its future developments were to a certain extent unpredictable. At the same time, in strict contrast to the Treaty establishing the European Coal and Steel Community of $1951,{ }^{16}$ the Treaty was signed for an unlimited period of time (Article 208). Consequently, the signatories of the Treaty faced two contradictory interests: on the one hand, there was interest to support the speedy development of the nuclear industry, and on the other hand the signatories also aimed at the possibility of future adjustments and amendments of the applicable provisions if the circumstances so required. ${ }^{17}$ Consequently, while the building of the nuclear industry was given priority by the executives of the six States, there was also awareness of the potential danger arising from the further development of this new technology. ${ }^{18}$ These two contradictory interests were reflected in several provisions of the Treaty, as outlined below.

Several articles provided for the future amendment of the scope of the application of the Treaty. Here, the provisions facilitating the promotion of nuclear research (Chapter 1) should be mentioned. In this area, the Treaty entrusted the Commission with the responsibility for promoting and facilitating nuclear research in the Member States and for complementing it by carrying out a Community research and training programme. The activity of the Commission in this respect should be carried out within the fields listed in Annex I to the Treaty. ${ }^{19}$ Community research was to be carried out by a Joint Nuclear Research Centre,

\footnotetext{
${ }^{16}$ Article 97 provided that this Treaty was concluded for a period of fifty years from its entry into force.

${ }_{17}$ The feeling of uncertainty concerning future developments of the nuclear industry was also reflected in other international conventions adopted in this period. For example, the Paris Convention on Third Party Liability in the Field of Nuclear Energy of 1960 defined 'nuclear installations', to which a special regime of liability and compensation is to be applied as 'reactors other than those comprised in any means of transport; factories for the manufacture or processing of nuclear substances; factories for the separation of isotopes of nuclear fuel; factories for the reprocessing of irradiated nuclear fuel; facilities for the storage of nuclear substances other than storage incidental to the carriage of such substances; and such other installations in which there are nuclear fuel or radioactive products or waste as the Steering Committee for Nuclear Energy of the Organisation shall from time to time determine'.

${ }^{18}$ In this regard, it is interesting to mention that a serious nuclear accident happened in the Windscale facility on the northwest coast of England on 25 October 1957, ie seven months after the Treaty was signed by the six States.

19 According to this Annex, the promoting and facilitating of nuclear research are to be carried out in the following fields: raw materials, physics applied to nuclear energy, the physical chemistry of reactors, processing of radioactive materials, and the application of radioisotopes.
} 
which was also commissioned by the Treaty to establish uniform nuclear terminology, a standard system of measurements and a central bureau for nuclear measurements. However, the scope of Community research was not considered to have been finally decided, ${ }^{20}$ as Article 4 provided for the possibility to amend the scope of Annex I in the future. ${ }^{21}$ Chapter 4, establishing a framework for facilitating investments in the nuclear industry, provides another example. Here, the Treaty provides that persons and undertakings engaged in the industrial activities listed in Annex II $^{22}$ should communicate to the Commission investment projects relating to new installations and also prospective replacements or conversions. The list of these industrial activities was also not considered to have been finally decided, as Article 44 also provided for the possibility to amend the scope of Annex II in the future. ${ }^{23}$ Finally, a similar possibility was provided by Article 92 concerning the list of goods and products to be covered by the legal regime of the nuclear common market (Chapter 9). ${ }^{24}$

Further, several articles provided for the possibility of future adjustments of all the chapters of the Treaty. Such a possibility concerned Chapter 6, establishing a framework for supplies of ores, source materials and special fissile materials in the Community. This framework was intended to be executed by the Euratom Supply Agency, which was commissioned by exclusive right concerning any deliveries from outside the Community. ${ }^{25}$ However, Article 76 explicitly opened the possibility for the future adjustment of the whole chapter, underling its 'provisional' char-

\footnotetext{
${ }^{20} \mathrm{~J}$ Grünwald, Das Energierecht der Europäischen Gemeinschaften: EGKS, Euratom, EG. Grundlagen, Geschichte, geltende Regelungen (De Gruyter Recht 2003) 197-198.

21 'This list may be amended by the Council, acting by a qualified majority on a proposal from the Commission. The latter shall consult the Scientific and Technical Committee established under Article 134.'

22 This Annex includes the mining of uranium and thorium ore, the concentration of such ores, the chemical processing and refining of uranium and thorium concentrates, the preparation of nuclear fuels, in any form, the fabrication of nuclear fuel elements, the production of uranium hexafluoride, the production of enriched uranium, the processing of irradiated fuels for the purpose of separating some or all of the elements contained therein, the production of reactor moderators, the production of hafnium free zirconium or compounds thereof, nuclear reactors of all types and for all purposes, facilities for the industrial processing of radioactive waste, set up in conjunction with one or more of the facilities specified in the list, and semi industrial installations intended to prepare the way for the construction of plants involved in any of these activities.

23 'The list of industrial activities referred to above may be altered by the Council, acting by a qualified majority on a proposal from the Commission, which shall first obtain the opinion of the Economic and Social Committee.'

24 'The provisions of this Chapter shall apply to the goods and products specified in the lists forming Annex IV to this Treaty. These lists may, at the request of the Commission or of a Member State, be amended by the Council, acting on a proposal from the Commission.'

${ }^{25}$ P Mengozzi, L' agenzia di Approvvigionamento dell' Euratom (A Giuffré 1964) 22-24.
} 
acter by setting an exact time limit for such adjustment. ${ }^{26}$ A very similar possibility for future adjustment was provided regarding the framework of safeguards, as established in Chapter 7. Here, Article 85 did not contain any explicit time limit for such adjustment, but merely referred to prospective 'new circumstances'. ${ }^{27}$ And finally, 'new circumstances' were identified as the reason for future adjustment concerning Chapter 9, which provides for a framework of the Community's exclusive ownership of special fissile materials. ${ }^{28}$ In this regard, Article 90 provides legal ground for prospective adjustment. ${ }^{29}$

Lastly, Article 197 also authorised the Council to further specify to which materials certain chapters are applicable. ${ }^{30}$ Such specification must be done by the Council by a qualified majority on a proposal from the Commission.

However, although several attempts have been made to use these provisions since the $1960 \mathrm{~s},{ }^{31}$ none have been successful. In particular, the provisions of Chapter 6 , dealing with the common supply policy, have never been applied by the Commission vis-à-vis the Member States

26 'On the initiative of a Member State or of the Commission, and particularly if unforeseen circumstances create a situation of general shortage, the Council may, acting unanimously on a proposal from the Commission and after consulting the European Parliament, amend the provisions of this Chapter. The Commission shall inquire into any request made by a Member State. Seven years after 1 January 1958, the Council may confirm these provisions in their entirety. Failing confirmation, new provisions relating to the subject matter of this Chapter shall be adopted in accordance with the procedure laid down in the preceding paragraph.'

${ }_{27}$ 'Where new circumstances so require, the procedures for applying the safeguards laid down in this Chapter may, at the request of a Member State or of the Commission, be adapted by the Council, acting unanimously on a proposal from the Commission and after consulting the European Parliament. The Commission shall examine any such request made by a Member State.'

${ }^{28}$ See P Bohm, 'Die juristische Problematik der europäischen Kernbrennstoffeigentums' (1961) Neue Juristische Wochenschrift 1553; P Bohm, 'Ownership of Nuclear Materials in Euratom' (1962) 11(2) AJCL 167; H Haedrich, 'Das Eigentum der Europäischen Atomgemeinschaft an Kernbrennstoffen' in Festschrift für C. F. Ophüls (Verlag Müller 1965); R Lukes, 'Die Eigentumsregelungen für die besonderen spaltbaren Stoffen im Euratomvertrag' in Zweites Deutsches Atomrechts-Symposium (Carl Heymans 1974); G Vedel, 'Le régime de propriété dans le Traité Euratom' (1957) AFDI 586.

29 'Where new circumstances so require, the provisions of this Chapter relating to the Community's right of ownership may, at the request of a Member State or of the Commission, be adjusted by the Council, acting unanimously on a proposal from the Commission and after consulting the European Parliament. The Commission shall examine any such request made by a Member State.,

30 This is the case of special fissile materials, source materials and ores.

${ }^{31}$ For details about these attempts, see W Manig, Die Änderung der Vorsorgungs- und Sicherheitsvorschriften des Euratom-Vertrages durch die nachfolgende Praxis (Nomos Verlag 1993) 125-127. 
as foreseen in the Treaty. ${ }^{32}$ In this regard, the Court of Justice has had to deal with the question of whether these provisions remain valid or whether they have become obsolete in the meantime. In this regard, the Court argued, that:

Even an abstention by the Council from exercising the powers which it holds under the second paragraph of Article 76 with a view to adapting the provisions of Chapter 6 of the Treaty in the light of experience, cannot have the effect of causing these provisions to lapse, either immediately or at any subsequent date. Until the Council's decision, the provisions of Chapter 6 are only maintained on a temporary basis, so that at any moment there may be substituted for them a set of new provisions constituting a different supply system..$^{33}$

While confirming the temporary character of Chapter 6, the Court also argued that:

It cannot be presumed that provisions of the Treaty have lapsed. The Member States agreed to establish a Community of unlimited duration, having permanent institutions, invested with real powers, stemming from a limitation of authority or a transfer of powers from the States to that Community. Powers thus conferred cannot, therefore, be withdrawn from the Community and restored to the Member States except by virtue of an express provision of the Treaty. ${ }^{34}$

Hence, while approving the validity of the provisions of Chapter $6,^{35}$ the Court also reaffirmed the future possibility to provide for further adjustments. ${ }^{36}$

The provisions of the Treaty also today still provide for the possibility of further amendments, adjustments or specification of the scope of application. This provides the possibility to change the scope of application of the Treaty without the need for further ratification by the Member States. Such a specific regime concerns six out of ten chapters

\footnotetext{
${ }^{32}$ See I Alehno, 'The Euratom Supply Agency: Past, Present and Future' in Nuclear Inter Jura 2009 (Bruylant 2010); Allen (n 10); A Bouquet, 'How Current Are Euratom Provisions on Nuclear Supply and Ownership in View of the European Union's Enlargement?' (2001) 68 NLB 7; T Cusack, 'External Relations of the European Atomic Energy Community in the Fields of Supply and Safeguards: Backgrounds and Developments' in Yearbook of European Law (OUP 1983); J Mennicken, 'Die Gemeinschaftlichen Versorgung der EG-Staaten mit Kernbrennstoffen: Probleme der Euratom-Versorgungsagentur' (1974) 34(7) Europa-Archiv 747.

${ }^{33}$ Case C-7/71 Commission v French Republic [1971] ECR I-121, paras 23-26.

${ }^{34}$ Ibid, paras 18-20.

${ }^{35} \mathrm{E}$ Gruber, 'Das Urteil des Europäischen Gerichtshofes zur Fortgeltung der Versorgungsvorschriften des Euratomvertrages' (1972) Atomwirtschaft 221, 221-222.

${ }^{36} \mathrm{~J}$ Heber, 'Observations sur l'arrêt rendu le 14 décembre 1971 par le Cour de justice des Communités européennes dans l'affaire7/71' (1972) 9(4) RTDEur 299.
} 
of the Treaty, ie the framework for the promotion of research (Chapter 1), investments (Chapter 4), supplies (Chapter 6), safeguards (Chapter 7), property ownership (Chapter 8) and the common nuclear market (Chapter 9). Consequently, the existence of these provisions underlines the peculiar nature of the Euratom Community.

\section{A static community}

Originally, the Treaty provided for a number of provisions ${ }^{37}$ aimed at reaching the goal to 'create the conditions necessary for the development of a powerful nuclear industry'. One can identify several of these provisions which have been used by the Euratom Community to address the speedy development of the nuclear industry:

1. Chapter 1 provides for the Community research and training programmes in its Article $7 .{ }^{38}$ The first of the programmes was established directly by the Treaty ${ }^{39}$ for the years 1958-1962. The second of the programmes was realised subsequently from 1963 to 1967 with the development of Euratom's own model of nuclear reactor. ${ }^{40}$ However, it took six years to find consensus on establishing the $3^{\text {rd }}$ Community Research and Training Programme (1973-1976). Subsequently, research development became disintegrated with support also coming from the programmes of the European Economic Community. Consequently, the $4^{\text {th }}$ Community Research and Training Programme was not started before 1994 (from 1994 to 1998$)$, followed by the $5^{\text {th }}(1998-2000), 6^{\text {th }}$ (2002-2006), $7^{\text {th }}(2007-2011)$ and, most recently, the $8^{\text {th }}$ Programme (2014-2018).

\footnotetext{
${ }^{37}$ This concerns provisions on the promotion of research (Chapter 1), dissemination of information (Chapter 2), investments (Chapter 4), joint undertakings (Chapter 5), supplies (Chapter 6), property ownership (Chapter 8) and the common nuclear market (Chapter 9).

38 'Community research and training programmes shall be determined by the Council, acting unanimously on a proposal from the Commission, which shall consult the Scientific and Technical Committee. These programmes shall be drawn up for a period of not more than five years. The funds required for carrying out these programmes shall be included each year in the research and investment budget of the Community. The Commission shall ensure that these programmes are carried out and shall submit an annual report thereon to the Council. The Commission shall keep the Economic and Social Committee informed of the broad outlines of Community research and training programmes.'

39 The first Community Research and Training Programme was established by the then existing Article 215 of the Treaty. The content of this programme was provided by Annex $\mathrm{V}$ to the Treaty. The text of this Annex is to be found in G Lake, 'The Main Provisions of the Euratom Treaty' in The European Parliament and the Euratom Treaty: Past, Present and Future (Directorate General for Research 2002).

40 The 'ORGEL' (ORGanique Eau Lourde) Project.
} 
2. Chapter 4 provides for the publishing of Nuclear Illustrative Programmes (PINC) in its Article 40. ${ }^{41}$ The aim of these programmes is to facilitate coordinated development in investment efforts by undertakings in the nuclear industry. Altogether, six such illustrative programmes have been published. ${ }^{42}$ The recent Nuclear Illustrative Programme was launched in 2017.43

3. Chapter 5, providing for rules of joint undertaking, may serve as another good example of Euratom's activity in this area. ${ }^{44}$ Based on these rules, eight joint undertakings were established under the aegis of the Euratom Community from 1961 to 1975, the 'Société d'énergie nucléaire franco-belge des Ardennes (Senna)' being the first of them. ${ }^{45}$ Recently, the 'Fusion for Energy (F4E)', established to tackle the issue of nuclear fusion, represents the most salient example of such joint undertaking.

However, a number of the Treaty's provisions have remained unused due to the preference given to national instead of Community programmes (referred to as 'nuclear nationalism' by some authors ${ }^{46}$ ) or due to the hostility of certain Member States towards the execution of some of Euratom's competences. ${ }^{47}$

\footnotetext{
41 'In order to stimulate action by persons and undertakings and to facilitate coordinated development of their investment in the nuclear field, the Commission shall periodically publish illustrative programmes indicating in particular nuclear energy production targets and all the types of investment required for their attainment. The Commission shall obtain the opinion of the Economic and Social Committee on such programmes before their publication.' This provision was inspired by Article 46 of the Treaty establishing the European Coal and Steel Community of 1951.

${ }^{42}$ In 1966, 1972, 1985, 1990, 1997 and 2007.

${ }^{43}$ COM (2017) 237 final.

${ }^{44}$ See C Colliard, 'Les enterprises communes (OCDE et Euratom)' (1979) 1 Journées soc législ comp 231; C Enger, 'Internationale öffentliche Unternehmen' (1995) 59 RabelsZ 495; E Libbrecht, 'Les caractères essentiels des entreprises communes de l'Euratom' (1971) 7 RTD Eur 623.

${ }^{45}$ See Grünwald (n 20) 139-140 for a complete overview of these joint undertakings.

${ }^{46}$ Scheinman (n 5).

${ }^{47}$ See G Andreini, 'Euratom: An Instrument to Achieve a Nuclear Deterrent? French Nuclear Independence and European Integration during the Mollet Government' (2000) 6(1) Revue d'Intégration Européenne 104; A Cocatre-Zilgien, 'Euratom et Marché commun devant le Parlement français' (1957) 3 AFDI 517; M O'Driscoll, 'The Origins and Early History of Euratom, 1955-1968' in The European Parliament and the Euratom Treaty: Past, Present and Future (DG Research 2002); J Grünwald, 'Euratom Treaty History and the Way Forward' in Nuclear Inter Jura 2007: Proceedings/Actes du Congrés (Bruylant 2008); HL Nieburg, 'European Atomic Energy Community: A Study in Coalition Politics ' (1963) 15(5) World Politics 597; CM Vassanelli, 'Euratom: Critical Review of Selected Regulatory Functions' (1968-1969) 52(3) Marquette Law Review 355.
} 
The provisions of the Treaty offer numerous examples ${ }^{48}$ of competences unused by the Euratom Community for one or both of the reasons mentioned above:

1. The establishing of an institution of university status, dealing with nuclear education, was foreseen in Article 9. However, due to the obvious preference given to national research programmes instead of common research undertakings, such an institution has never been established.

2. Further, Charter 6, dealing with supplies of ores, source materials and special fissile materials, provides for several examples of competences unused due to the hostility of certain Member States. Thus, the Commission has never made any appropriate recommendations regarding revenue or mining regulations as provided for in Article 71. Neither the commercial, nor the emergency stocks of ores, source materials and special fissile materials, as provided for in Article 72, have ever been established. The Euratom Supply Agency has also never used its right of option (Article 57), nor has it used its exclusive right (Article 64) concerning deliveries of ores, source materials and special fissile materials from third States. Instead of these competences, a simplified contracting procedure has been gradually introduced, as foreseen in Article $66 .{ }^{49}$ Consequently, the concept of the exclusive ownership by the Euratom Community of special fissile materials, as established by Chapter 8 (Article 86), remains 'an empty shell'. ${ }^{50}$

3. Finally, a directive 'to facilitate the conclusion of insurance contracts covering nuclear risks' (Article 98) has never been issued by the Council. ${ }^{51}$ In this case, the reason for Euratom inactivity ${ }^{52}$

\footnotetext{
${ }^{48}$ For a detail overview of such 'dormant' competences, see J Grünwald, 'From Challenge to Response: Dormant Powers in Euratom Law' in C Raetzke (ed), Nuclear Law in the EU and Beyond (Nomos Verlag 2014).

49 'Should the Commission find, on application by the users concerned, that the Agency is not in a position to deliver within a reasonable period of time all or part of the supplies ordered, or that it can only do so at excessively high prices, the users shall have the right to conclude directly contracts relating to supplies from outside the Community, provided that such contracts meet in essential respects the requirements specified in their orders.'

${ }^{50}$ A Bouquet, 'The Mysteries of the Euratom Community's Ownership Right' in V Lamm (ed), Nuclear Inter Jura (Archaeolingua 2002).

${ }^{51} \mathrm{M}$ Wathelet, 'Clarification de la base légale pour une intervention au niveau de l'UE dans le domaine de la responsabilité nucléaire' in M Beyens, D Philippe, P Reyners (eds), Prospects of a Civil Nuclear Liability Regime in the Framework of the European Union (Bruylant 2012).

${ }^{52}$ In this respect, two recommendations were issued by the Euratom Community to address the issue. See the Commission Recommendation 65/42/Euratom of 28 October
} 
was the fact that a regional legal framework covering the field of nuclear liability and compensation was established in the meantime by corresponding international conventions.

However, the Treaty has survived the last 60 years without any considerable amendments. Most of the changes in the text of the Treaty, ${ }^{53}$ made over the last decades, were driven by the accession of new Member States and the subsequent need to reflect these Member States in the institutional structure of the Community. ${ }^{54}$ Consequently, at the beginning of the new millennium, the Treaty became subject to vigorous criticism. Hence, it was argued, that the Treaty was 'outdated, undemocratic, and biased towards the electronuclear industry'. ${ }^{55}$

If the EEC was initially predominantly 'functional', the EU is now predominantly (or at least increasingly) 'humanist'. ${ }^{56}$ The Euratom has not undergone the same evolution. In contrast to the EU, the Euratom's tasks (or objectives) have never been amended. They are the same as when the Treaty was adopted. ${ }^{57}$

Reflecting this criticism, several proposals addressing the question of Euratom were prepared at the beginning of the new millennium. ${ }^{58}$

1965 [1965] OJ 196/2995 and the Commission Recommendation 66/22/Euratom of 6 July 1966 on the harmonisation of legislation applying the 1960 Paris Convention [1966] OJ 136/2553.

${ }^{53}$ For a very detailed overview of these changes, see $J$ Grünwald, 'Neuere Entwicklungen des Euratom-Rechts' (1998) 1 Zeitschrift für Europarechtliche Studien 276, fn 6.

${ }^{54}$ It was the Merger Treaty of 1965 (entered into force on 1 July 1967) which combined the executive bodies of the three European Communities (the European Coal and Steel Community, the European Atomic Energy Community, and the European Economic Community) into a single institutional structure.

${ }^{55}$ It was argued that in the framework of the Treaty, there is 'no requirement for the Council to do anything more than formally consult the European Parliament on substantive issues. Under the provisions of the Treaty, the European Economic and Social Committee and the Scientific and Technical Committee do have similar consultation role as the European Parliament. In addition, Article 101 excludes the European Parliament from involvement in international agreements based on its terms'. For further details of this criticism, see P Barnes (n 9) 193-194. A more positive view on Euratom was presented in J Grünwald, 'Euratom - Vertrag: nie war er so wertvoll wie heute' (2000) 11(4) Europäische Zeitschrift für Wirtschaftsrecht 481 .

${ }^{56}$ A Södersten (n 15) 67-68.

${ }^{57}$ Ibid.

58 The Penelope Proposal aimed to address the question of Euratom by abolishing the provisions of Chapter 6 (supplies), Chapter 8 (property ownership) and Chapter 9 (Common nuclear market) as these were considered obsolete. Further, the provisions of Chapter 3 (health and safety), Chapter 4 (investments), Chapter 5 (joint undertakings) and Chapter 7 (safeguards) were intended to be incorporated into the text of a new Regulation, dealing with peaceful uses of nuclear energy. The Praesidium Proposal aimed at the further existence of the Treaty. However, Article 184, granting Euratom a legal personality, was intended to be cancelled. Finally, the Nagy Proposal aimed at the full abolishment of the Treaty and at the incorporation of the provisions on health and safety into the text of the Treaty establishing a 
However, none of these proposals were accepted and the further existence of the Treaty was subsequently confirmed by the Treaty of Lisbon in $2007 .{ }^{59}$

Thus, after six decades of Euratom's existence, 'the conditions necessary for the development of a powerful nuclear industry' as provided for by the Treaty remain in their original version. The Euratom Community continues to exist as an independent legal personality, parallel to the European Union. The legal framework that has been established by the Euratom Community has the nature of leges speciales in relation to the legal framework established by the European Union. And consequently, the latter is to be applied subsidiarily in cases where explicit special regulation is missing. ${ }^{60}$

\section{A flexible community}

In her paper on Euratom Community perspectives at the start of the new millennium, Christiane True gave several reasons for the static nature of the Treaty. ${ }^{61}$ The unwillingness of the majority of the Member States to pursue any considerable amendment of the Treaty was explained by the delicate nature of the subject, by the existence of a number of contradictory interests, and also by the fact that the Treaty itself does not provide for any explicit obligation to use nuclear energy in the territory of the Member States. However, the Treaty has also proved to be quite flexible, in particular in the protection of health and safety. This is due to the fact that while the competences conferred to Euratom originally included only the field of radiological protection, they were later interpreted in a broader sense also to cover issues of nuclear safety.

Here, Chapter 3 provides for several competences of the European Commission in the area of health and safety. These competences are classified $^{62}$ as general competences and special competences. Under gen-

Constitution for Europe. For details, see M Jasper, 'Vertragsentwurf des europäischen Konvents und mögliche Konsequenzen für das Energie- bzw. Atomrecht' (2003) 7(3) Zeitschrift für neues Energierecht 292; and C True, 'The Euratom Community Treaty's Prospects at the Start of the New Millennium' (2006) 1(1) IJNucL 247.

59 Protocol No. 2 to the Treaty of Lisbon of 2007 introduced several amendments to the Treaty establishing the European Atomic Energy Community, which were, however, rather of an institutional and financial nature. The newly introduced Article 106a provides which provisions of the Treaty on European Union and of the Treaty on the Functioning of the European Union are also to be applicable to Euratom.

${ }^{60}$ An outstanding overview of mutual relations between both legal frameworks is presented in R Ptasekaite, The Euratom Treaty vs Treaties of the European Union: Limits of Competence and Interaction (Swedish Radiation Safety Authority 2011) 30.

${ }^{61}$ True (n 58).

62 Grünwald (n 20) 223-224. 
eral competence (Article 38), the European Commission should make recommendations to the Member States regarding the level of radioactivity in the air, water and soil. ${ }^{63}$ Further, the Commission possesses several special competences in this area. In the first place, any Member State in whose territories particularly dangerous experiments are to take place must take additional health and safety measures, on which they must first obtain the opinion of the Commission (Article 34). Additionally, the Commission has the right of access to facilities carrying out continuous monitoring of the level of radioactivity in the air, water and soil and it may verify their operation and efficiency (Article 35). Finally, Article 37 authorises the Commission to issue opinions on the plans of the Member States for the disposal of radioactive waste in whatever form.

However, it was the norm-making competence of the Euratom Community in the area of health and safety which gradually became a tool to address a relative wide range of issues. Pursuant to Article 30, basic standards are to be laid down within the Community for the protection of the health of workers and the general public against dangers arising from ionising radiation. ${ }^{64}$ These basic standards are to be worked out by the Commission after it has obtained the opinion of a group of persons appointed by the Scientific and Technical Committee from among scientific experts, and in particular public health experts, in the Member States. The Commission must obtain the opinion of the Economic and Social Committee on these basic standards (Article 31). In this respect, each Member State is obliged to lay down the appropriate provisions, whether by legislation, regulation or administrative action, to ensure compliance with the basic standards which have been established.

The question of the applicability of the rules laid down in Chapter 3 has become the subject of several decisions rendered by the Court of Justice.

1. On one hand, the Court had to deal with the question of whether the provisions of Chapter 3 are also applicable to military installations. ${ }^{65}$ Concerning the application of Article 37 (plans for

\footnotetext{
${ }^{63}$ Further, in cases of urgency, Article 38 authorises the Commission to issue a 'directive' requiring the Member State concerned to take, within a period laid down by the Commission, all necessary measures to prevent infringement of the basic standards and to ensure compliance with regulations.

64 Pursuant to Article 30, these basic standards must contain maximum permissible doses compatible with adequate safety, maximum permissible levels of exposure and contamination, and fundamental principles governing the health surveillance of workers.

65 The text of the Treaty is silent concerning its applicability (or inapplicability) to military installations. The only indirect reference to these types of installations is contained in $\mathrm{Ar}$ ticle 84, which provides that the safeguards may not extend to materials intended to meet defence requirements which are in the course of being specially processed for this purpose
} 
the disposal of radioactive waste) to a military installation, ${ }^{66}$ the Court argued that:

The evidence on interpretation to be taken into consideration cannot be limited to the historical background to the drawing up of the Treaty, or to the contents of the unilateral declarations made by the representatives of certain States who took part in the negotiations which led to the signature of that Treaty. As the Advocate General rightly pointed out in points 80 and 81 of his Opinion, it is clear from that background and certain declarations mentioned in the travaux préparatoires of the Treaty that its possible application to the military uses of nuclear energy was envisaged and discussed by the representatives of the States who took part in those negotiations. However, it is also apparent that they held differing opinions on that issue and that they decided to leave it unresolved. Consequently, the guidance provided by that evidence is not sufficient for it to be asserted that the framers of the Treaty intended to make its provisions applicable to military installations and military applications of nuclear energy. ${ }^{67}$

However, the Court also stated, that:

An interpretation of Article 37 to the effect that the Member State concerned might decide both the time from which a military source of radioactive waste must be regarded as civil waste and the actual content of the data which must be communicated to the Commission would be in contradiction with the purpose of that provision. (...) Furthermore, an interpretation of Article 37 which allowed Member States such discretion as to the time for communicating data and its content would be a

or which, after being so processed, are, in accordance with an operational plan, placed or stored in a military establishment'. Further, Article 86 stipulates, that 'the Community's right of ownership shall extend to all special fissile materials which are produced or imported by a Member State, a person or an undertaking and are subject to the safeguards provided for in Chapter 7'. Consequently, it used to be argued that Chapter 7 (safeguards) and Chapter 8 (property ownership) are not applicable to any military installations. On the contrary, according to some interpretations, the provisions of other chapters were to be applied also to military facilities. Such an interpretation was underlined by the fact that France proceeded according to Article 34 when experimenting with nuclear explosions in the Sahara at the beginning of the 1960s. Besides, Article 52, which provides that the Euratom Supply Agency 'may not discriminate in any way between users on grounds of the use which they intend to make of the supplies requested unless such use is unlawful', was interpreted in favour of the applicability of Chapter 6 (supplies) on military installations. In detail, see A Breda, 'Alla ricerca del delicato equilibrio tra protezione della salute e difesa della sicurezza nazionale nell' ambito del Trattato Euratom' (2005) 2(4) DPCE 1126.

${ }^{66}$ The case concerned the Jason reactor that was operated by the United Kingdom Ministry of Defence at the Royal Naval College Greenwich from 1962 to 1996. During this time, it was used to train naval and dockyard personnel in reactor physics and as a research tool in support of the Naval Nuclear Propulsion Programme of the Ministry of Defence. At the end of this period, Jason was dismantled upon the successful application for authorisation to the United Kingdom's Environment Agency for England and Wales.

${ }^{67}$ Case C-61/03 Commission v United Kingdom [2005] ECR I-2477, para 29. 
source of dispute and would undermine the effective application of that provision. ${ }^{68}$

In another case, the Court had to deal with the issue of the applicability of the basic standards to the operation of a nuclear-powered vessel. ${ }^{69}$ In this respect, the Court argued that:

To accept that in such a situation the obligation laid down in (...) the directive is incumbent none the less on Member States would amount to recognising that the provisions of the Treaty concerning health and safety, in particular Article 31, which provides the basis for that directive, are different in scope from the other provisions of that Treaty. Whether the provisions of that Treaty applied to activities within the military sphere would thus depend on the nature and scope of the obligations which those provisions impose on Member States. It would therefore be necessary to assess in each case the damage which performance of those obligations may cause to the essential national defence interests of those States. ${ }^{70}$

Consequently, the Court argued, that 'as the scope of provisions of secondary legislation cannot validly exceed that of their legal basis, the inapplicability of Article 31 to military activities necessarily means that the directive does not apply to such activities. ${ }^{71}$ Consequently, the provisions of the Treaty proved to be flexible enough to respect certain vital interests of its Member States in the area of defence policy by enabling a rather restrictive interpretation of its scope. ${ }^{72}$

2. On the other hand, the Court had to deal with the question of to what extent Chapter 3 is applicable to the issues of nuclear safety. The Treaty lacks any explicit reference to the safety of nuclear installations. Consequently, the signatories of the Treaty

\footnotetext{
${ }^{68}$ Ibid, paras 40-41.

${ }^{69}$ This case concerned the nuclearpowered Royal Navy submarine HMS Tireless, docked in the harbour of Gibraltar for repair operations following a minor incident with its nuclear propulsion reactor while on the Mediterranean Sea. These repair operations lasted until May 2001. In the course of 2000 , the Commission received six complaints relating to the repair operations, which led it to request the United Kingdom government to provide information regarding the operations and the information given to the public about health protection measures to be taken in the event of a radiological emergency.

${ }^{70}$ Case C-65/04 Commission v United Kingdom [2006] ECR I-2239, paras 24-25.

${ }^{71}$ Ibid, para 27.

${ }^{72}$ However, in Case C-65/04, the Court also stated, that it is important to note, however, that that finding does not by any means reduce the vital importance of the objective of protecting the health of the public and the environment against the dangers related to the use of nuclear energy, including for military purposes. In so far as the EAEC Treaty does not provide the Community with a specific instrument in order to pursue that objective, it is possible that appropriate measures might be adopted on the basis of the relevant provisions of the EC Treaty' (para 28).
} 
were originally not willing to commission Euratom with any competences in this sensitive field. Therefore, Euratom restricted its activities here to two unbinding recommendations. ${ }^{73}$ This kind of response to the issues of nuclear safety, arising in the post-Chernobyl period, was not considered appropriate by many stakeholders. Thus, it was felt that 'the fact that the Member States retain exclusive competence over the technological aspects of nuclear safety does not prevent the Community from adopting legislation which establishes certain safety requirements, authorisation requirements, inspection and assessment requirements or enforcement mechanisms'. ${ }^{74}$

Consequently, dealing with the issue of the Community's accession to the Convention on Nuclear Safety of 1994, the Court argued, that:

Even though the Euratom Treaty does not grant the Community competence to authorise the construction or operation of nuclear installations, under Articles 30 to 32 of the Euratom Treaty the Community possesses legislative competence to establish, for the purpose of health protection, an authorisation system which must be applied by the Member States. Such a legislative act constitutes a measure supplementing the basic standards referred to in that article. (...) Under Article 37 of the Euratom Treaty, the Community possesses competence as regards 'any plan for the disposal of radioactive waste in whatever form' if the implementation of that plan is liable to result in the radioactive contamination of the water, soil or airspace of another Member State. That fact provides sufficient grounds to conclude that the Community possesses competence in the field covered by Article 17 of the Convention. The measures required by Articles 18 and 19 of the Convention concerning the design, construction and operation of nuclear installations can be the subject of the provisions which the Member States lay down to ensure, in accordance with the first paragraph of Article 33 of the Euratom Treaty, compliance with the basic standards. However, the Commission has competence to make recommendations for harmonising those provisions, as is clear from the second paragraph of Article 33 of the Euratom Treaty, interpreted in the light of the considerations set out in paragraphs 75 to 83 of the present judgment. The Member States are required to assist in drawing up those recommendations through the communications referred to in the third paragraph of Article 33 of the Euratom Treaty. ${ }^{75}$

\footnotetext{
${ }^{73}$ Published in 1975 and 1992.

${ }^{74}$ Case C-29/99 Commission v Council [2001] ECR I-860, Opinion of AG Jacobs, paras 166-167.

75 Case C-29/99 Commission v Council [2002] ECR I-734, paras 89, 103 and 105.
} 
While being originally intended mainly ${ }^{76}$ for the purposes of the further development of the nuclear industry (in particular by promoting nuclear energy by common research activities, investment coordination and establishing joint undertakings), Euratom has been gradually transformed into a Community establishing binding standards of nuclear safety in order to protect citizens and the environment. ${ }^{77}$ The extensive interpretation of the competences arising from the Treaty opened the doors for a new period of legislative activity. ${ }^{78}$ In 2009 , the issue of nuclear safety became the subject of legal regulation under the Euratom Community. ${ }^{79}$ Subsequently, in 2011, a directive was issued to address the issue of safety regarding spent fuel and radioactive waste management. ${ }^{80}$ In response to the 2011 Fukushima nuclear accident, risk and safety assessments ('stress tests') were carried out on all nuclear power plants situated in the territory of the Euratom Community. Neighbouring countries were also associated with this, and Switzerland and Ukraine participated fully. Beyond this, the European Commission encouraged and cooperated with nuclear regulators around the world to perform similar exercises. The aim of the assessments was to check whether the safety standards used when specific power plants received their licences were sufficient to cover unexpected extreme events. Specifically, the tests measured the ability of nuclear facilities to withstand damage from hazards such as earthquakes, flooding, terrorist attacks or aircraft collisions. Subsequently, the results of these 'stress tests' were reflected in the amendment of the nuclear safety directive in $2014 .{ }^{81}$

Further, the Euratom Community also became involved in nuclear safety cooperation with third countries, in particular through the

\footnotetext{
${ }^{76}$ Only ten out of 106 articles of Title II of the Treaty originally dealt with the issues of protection of health and safety. In contrast to this, 18 articles were devoted to issues of dissemination of information, licences and patents in the nuclear field, and 21 articles dealt with issues of the supply of ores, source materials and special fissile materials.

${ }^{77}$ W Schroeder, 'Die Euratom - auf dem Weg zu einer Umweltgemeinschaft' (1995) 7(2) Deutsches Verwaltungsblatt 322.

${ }^{78}$ See M Garribba, A Chirtes and M Nauduzaite, 'The Directive Establishing a Community Framework for the Nuclear Safety of Nuclear Instrallations' (2009) 84 Nuclear Law Bulletin 23; I Kacem, 'Safety for Nuclear Installations, Spent Nuclear Fuel and Radioactive Waste Management in the European Union: A Legal Analysis' (2004) 13(2) EEER 109; M Sousa Ferro, 'The Future of Regulation of Nuclear Safety in the EU' (2008) 2(2) IJNucL 149.

79 Council Directive 2009/71/Euratom of 25 June 2009 establishing a Community framework for the nuclear safety of nuclear installations [2009] OJ L172/18.

${ }^{80}$ Council Directive 2011/70/Euratom of 19 July 2011 establishing a Community framework for the responsible and safe management of spent fuel and radioactive waste [2011] OJ L199/48.

${ }^{81}$ Council Directive 2014/87/Euratom of 8 July 2014 amending Directive 2009/71/Euratom establishing a Community framework for the nuclear safety of nuclear installations [2014] OJ L219/42.
} 
platform called 'Instrument for Nuclear Safety Cooperation (INSC)'. The first INSC was established ${ }^{82}$ for the period 2007 to 2013 to support EU activities and promote the highest levels of nuclear safety, radiation protection and effective nuclear safeguards globally. In 2013, a second INSC was established ${ }^{83}$ for the period 2014 to 2020 , with a total budget of 225 million. Major elements of INSC cooperation with third countries have recently included the promotion and development of effective regulatory frameworks, technical support to nuclear regulatory bodies, and national technical safety organisations. Activities have expanded to the field of nuclear safeguards, radioactive waste management and emergency preparedness.

Taking these very recent developments into consideration, it can be seen that this new role of Euratom is far from the role originally conferred to this Community by the signatories of the Treaty. However, this new role has naturally become the subject of criticism in the sense that it exceeds the limits established by the Member States in the text of the Treaty. ${ }^{84}$

\section{Conclusions}

The Treaty establishing the European Atomic Energy Community has largely remained in its original version of 1957 until today. Given its age and its largely unamended state, the Treaty has often been called a 'fossil', particularly by those who wish to phase out nuclear technology for energy generation altogether. There are also some features that are open to more general criticisms: these include provisions which do not appear to meet today's requirements, the existence of provisions of a provisional nature, and of provisions which have never been applied as intended by the signatories of the Treaty. Very recently, Anna Södersten has argued that 'while the Euratom has some important functions, the EU could equally perform many of these functions' and that 'given the expansion of EU competencies, there is no longer a need for the Euratom Treaty as a separate body'. ${ }^{85}$ However, the new millennium led to a considerable shift in Euratom's legislation: following the judgment of the Court of Justice of the European Union concerning Euratom's accession to the Convention on Nuclear Safety (2001), directives regulating the area of nuclear safety

\footnotetext{
${ }^{82}$ Council Regulation (Euratom) No 300/2007 of 19 February 2007 establishing an Instrument for Nuclear Safety Cooperation [2007] OJ L81/1.

${ }^{83}$ Council Regulation (Euratom) No 237/2014 of 13 December 2013 establishing an Instrument for Nuclear Safety Cooperation [2014] OJ L77/109.

${ }^{84}$ M Sousa Ferro, 'Directive 2009/71/Euratom: The Losing Battle against Discrimination and Protection of Sovereignty' (2009) 2(3) International Journal of Nuclear Law 295.

85 Södersten (n 15) 234.
} 
and radioactive waste management have been enacted. Thus, although intended to be a 'provisional' Community, Euratom has been gradually transformed into an 'environmental Community's6 establishing binding legal norms for the protection of citizens and the environment, in particular in the field of nuclear safety. This new role of Euratom is quite far removed from the original purpose of the Community, which was in the beginning intended to support the growth of the nuclear industry rather than to impose safety restrictions on it. It is not a 'serpent' ${ }^{87}$ that we see here. Neither is it a phoenix,,$^{88}$ cyclically regenerating itself from its own ashes. Euratom is a true chameleon.

\footnotetext{
${ }^{86}$ Schroeder (n 77).

87 Prieto Serrano (n 11) 14.

${ }^{88}$ Barnes, 'The Resurrection of the Euratom Treaty' (n 9) 182.
} 